\title{
The Secret Face of Arhythmias: Obstructive Sleep Apnea Syndrome
}

\section{Aritmilerin Gizli Yüzü: Obstrüktif Uyku Apne Sendromu}

\author{
(D) Pınar Mutlu, (D) Merve Yılmaz, (D) N. Arzu Mirici \\ Çanakkale Onsekiz Mart University Faculty of Medicine, Department of Chest Diseases, Çanakkale, Turkey
}

\begin{abstract}
Obstructive Sleep Apnea syndrome (OSAS) is a clinical condition accompanied by episodes of respiratory arrest, sleep fragmentation, oxygen desaturation, and excessive daytime sleepiness due to obstructions in the upper airway during sleep. Contrary to popular belief, OSAS is much more common in society. In some patients, we can observe symptoms of OSAS easily; however, some of the patients may not indicate any symptoms. Although the interest and research on the causes of OSAS and the mortality rate associated with cardiovascular disease have increased, this relationship has still not completely understood. The results of several proven trusted clinical trials support the hypothesis that OSAS increases the risk of stroke, arrhythmias (atrial fibrillation, bradyarrhythmia, supraventricular tachycardia, ventricular arrhythmia), coronary artery disease, acute myocardial infarction, and cardiac arrest as much as essential or resistant hypertension. In this case report, we wanted to demonstrate OSAS as a cause of arrhythmia in a young obese patient without OSAS symptoms, and an arrhythmia that improved with OSAS therapy.
\end{abstract}

Keywords: Young patient, arrhythmia, Obstructive Sleep Apnea syndrome
Öz

Obstrüktif Uyku Apne sendromu (OUAS), uykuda üst hava yolundaki tıkanıklıklar nedeniyle uyku sırasında oluşan solunum durması epizotları, uyku fragmantasyonu, oksijen satürasyonu ve gündüz artmış uyku hali ile birlikte olan bir klinik tablodur. OUAS toplumda aslında sanılandan çok daha yaygındır. Bazı hastalarda OUAS semptomlarını çok rahat görebiliriz, ancak bazı hastalar hiç semptom vermeyebilir. Her ne kadar OUAS'nin nedenlerinin ve kardiyovasküler hastalığa bağlanmış ölüm oranının üzerine olan ilgi ve araştırmalar artsa da, hala bu ilişki tam olarak netleştirilememiştir. Temel olarak güvenilir klinik bulgular OSAS'nin, esansiyal ve dirençli hipertansiyonla olduğu kadar, felç geçirme riskini, kardiyak ritim bozukluklarını (atriyal fibrilasyon, bradiaritmi, supraventriküler taşikardi, ventriküler aritmi) koroner arter hastalığını, akut miyokard infarktüsünü ve kardiyak arresti arttırdığı hipotezini destekliyor. Biz de bu olguda OUAS semptomları olmayan genç obez bir hastada aritminin nedeni olarak OUAS ve OUAS tedavisi ile düzelen bir aritmiyi göstermek istedik.

Anahtar Kelimeler: Genç hasta, aritmi, Obstrüktif Uyku Apne sendromu

\section{Introduction}

Obstructive Sleep Apnea syndrome (OSAS) is characterized by episodes of recurrent complete (apnea) or partial (hypopnea) upper respiratory tract obstruction during sleep, and often, a decrease in blood oxygen saturation (1). The overall incidence ranges between $1 \%$ and $5 \%$, and varies between $4 \%$ and $8 \%$ in middle-aged men (2). The name Pickwickian syndrome (obesity-hypoventilation syndrome) was formerly used to describe hypercapnic, obese individuals with erythrocytosis who constantly nap during the day. The name was inspired by the fat, red-faced character named Joe in the novel "The Pickwick Papers", written in 1836 by Charles Dickens.
Although it was considered innocuous in the past, it has since been found to be associated with cardiovascular system problems, arrhythmia, and car accidents, with high mortality and morbidity rates (3). The gold standard diagnostic test is polysomnography. Treatment includes general measures, use of continuous positive airway pressure (CPAP) and bilevel positive airway pressure devices, surgical procedures to reduce obstruction, intraoral medication, and medical treatment.

\section{Case Report}

An obese (body mass index: $30 \mathrm{~kg} / \mathrm{m}^{2}$ ), 27 -year-old male patient presented with palpitations, dizziness, an intermittent feeling of panic, and flu-like symptoms. He had a history of

Address for Correspondence/Yazışma Adresi: Pınar Mutlu MD, Çanakkale Onsekiz Mart University Faculty of Medicine, Department of Chest Diseases, Çanakkale, Turkey Phone: +90 5052629529 E-mail: pinarmutlu78@yahoo.com ORCID-ID: orcid.org/0000-0002-7496-0026 Received/Geliş Tarihi: 15.08.2018 Accepted/Kabul Tarihi: 20.01.2019

${ }^{\circ}$ Copyright 2018 by Turkish Sleep Medicine Society / Journal of Turkish Sleep Medicine published by Galenos Publishing House. 
10 pack/years of cigarette smoking, occasional alcohol use, childhood febrile convulsions, and pneumonia. His father had hypertension. The medical histories of his mother and brother were unremarkable.

A physical examination yielded a blood pressure measurement of $120 / 80 \mathrm{mmHg}$, a pulse rate of $61 /$ minute, cardiac and pulmonary auscultation results within the normal limits, palpable peripheral pulses, and no evidence of peripheral edema. Hemogram, routine biochemistry, and thyroid function test results were normal. Troponin and creatine kinase-MB values were also within the normal limits. His heart rate was $60 \mathrm{bpm}$. Left axis deviation and left anterior hemiblock were present on the electrocardiogram. The chest X-ray findings were not abnormal.

With these findings, the patient was referred to a cardiologist. Echocardiographic evaluation revealed asymmetric septal hypertrophy and left ventricular diastolic dysfunction. The ejection fraction was $67 \%$. The patient was diagnosed with hypertrophic nonobstructive cardiomyopathy. The patient was examined in detail because of his complaints of palpitations and headache, and a Holter device was used to monitor heart activity. His heart rate was generally in normal sinus rhythm. Minimum (28 bpm), maximum (119 bpm) and median heart rates (74 bpm) were measured. A total of 115 ventricular beats were detected, while atrial beats, ventricular couplets and triplets, supraventricular and ventricular tachycardia were not detected. A total of 11 brief pauses of more than 2 seconds in duration were observed. The longest apneic attack lasted 4 seconds.

An electrophysiological study was performed based on the Holter results. Ventricular fibrillation was induced with programmed ventricular stimulation and electrical cardioversion was performed with 200 joules to achieve sinus rhythm. Given the cardiac arrest lasting for 4 seconds seen in the Holter results and inducible ventricular fibrillation, implantation of a pacemaker was recommended for the patient.

However, the patient had a nickel allergy, so pacemaker implantation could not be performed. Acetylsalicylic acid (Coraspin; Bayer AG, Leverkusen, Germany) was administered and intermittent Holter monitoring was scheduled. The heart rate was recorded, and a sinus type heart rhythm was detected during Holter monitoring performed 2 months later. Minimum (33 bpm), maximum (149 bpm), and median (75 $\mathrm{bmp}$ ) heart rates were recorded as indicated. A total of 364 ventricular and 26 atrial premature beats were detected. Three long pauses of 3 seconds in duration were recorded.

\begin{tabular}{|l|l|}
\hline \multicolumn{2}{|l|}{ Table 1. Polysomnography findings } \\
\hline Sleep efficiency & $82.7 \%$ \\
\hline Lowest saturation & $82 \%$ \\
\hline Average saturation throughout the night & 93.9 \\
\hline Apnea + hypopnea & $16.1 / \mathrm{h}$ \\
\hline Obstructive apnea & $0.1 / \mathrm{h}$ \\
\hline Central apnea & $0.0 / \mathrm{h}$ \\
\hline Mixed apnea & $0.0 / \mathrm{h}$ \\
\hline Hypopnea & $16.0 / \mathrm{h}$ \\
\hline
\end{tabular}

Holter monitoring performed 4 months later demonstrated a sinus rhythm with minimum (33 bpm), maximum (119 bpm) and median (77 bpm) heart rates. A total of 226 ventricular and 27 atrial premature beats, and 4 apneic episodes were recorded. A more detailed medical family history revealed that his father had sleep apnea. Polysomnography was performed though the patient did not have any obvious OSAS symptoms, such as night apnea or daytime drowsiness. The apnea-hypopnea index measurement was 16. The findings of polysomnography are given below (Table 1).

CPAP titration was performed with the diagnosis of OSAS. The auto-CPAP device was set at a pressure range of 5-8 $\mathrm{cm} \mathrm{H}_{2} \mathrm{O}$. The patient used this device for 2 months. After 2 months, repeat Holter monitoring indicated a sinus rhythm with minimum (38 bpm), maximum (127 bpm), and median (70 bpm) heart rates. Atrial beats were not observed, while 61 ventricular pulses were detected. No apneic episode was seen.

\section{Discussion}

OSAS is a complex and multifactorial disease. The most important risk factors are obesity (4), neck circumference, male gender, age (40-65 years), smoking (5), alcohol use (6), and decreased physical activity (7). Hypothyroidism (8), acromegaly (9), benzodiazepine use (10), structural disorders in the upper respiratory tract, and the use of exogenous testosterone (11) may be less frequently associated risk factors. In a few studies, genetic predisposition in first degree relatives has been shown to be associated with familial obesity (12).

From a pathophysiological point of view, in healthy individuals, cardiac vagal stimulation increases with drowsiness. Especially in non-rapid eye movement sleep, sympathetic nerve activity, blood pressure, and heart rate decrease during sleep (13). This normal relationship is impaired in people with respiratory disorders occurring during sleep, and during respiratory efforts to overcome the pharyngeal barrier induced by transient hypoxic and hypercapnic episodes. These episodes are characterized by changes in pulmonary volume, intrathoracic pressure, and micro-arousals. Therefore, patients with OSAS demonstrate changes in their hemodynamic parameters during the night. Heart rate, blood pressure, and cardiac output continually demonstrate variations in association with recurrent microarousals caused by ventilatory abnormalities. Following cessation of apnea, an increase in heart rate and blood pressure due to a decrease in left ventricular ejection volume is seen. The main contributors to the development of hemodynamic modifications in patients with OSAS include hypoxemia, hypercapnia, changes in pulmonary volume/intrathoracic pressure, and microarousals. This cause and effect relationship was investigated in OSAS patients and healthy subjects, and all of these factors were found to contribute to changes to the autonomic nervous system in the long-term, the formation of reactive oxygen species, and endotracheal dysfunction. Metabolic abnormalities contribute to the increase in cardiovascular risk (14).

OSAS has various adverse consequences affecting the cardiovascular, neurological, pulmonary, endocrine, nephrological, gastrointestinal, and hematological systems, as well as psychiatric status. 
In our case, the effects included arrhythmia. The most common arrhythmias seen in OSAS are intermittent ventricular tachycardia, sinus arrhythmia with apnea induced bradycardia, and subsequent tachycardia occurring after apnea, seconddegree atrioventricular block, and premature ventricular beats $(15,16)$. In our case, premature ventricular and atrial beats and apneic episodes were detected during Holter monitoring. Regular use of a CPAP device was successful in eliminating the apneic attacks. As a result, we think that polysomnography should be performed in young patients with arrhythmias, despite a lack of underlying symptoms of OSAS.

\section{Ethics}

Informed Consent: It was taken.

Peer-review: Internally peer-reviewed.

\section{Authorship Contributions}

Surgical and Medical Practices: Concept: P.M., M.Y., Design: P.M., M.Y., A.M., Data Collection or Processing: A.M, MY, Analysis or Interpretation: P.M., M.Y., Literature Search: P.M., A.M., M.Y., Writing: P.M., A.M., M.Y.

Conflict of Interest: No conflict of interest was declared by the authors.

Financial Disclosure: The authors declared that this study received no financial support.

\section{References}

1. Partinen $M$, Jamieson A, Guilleminault C. Long- term outcome for obstruktive sleep apnea syndrome patients: mortality. Chest 1988;94:1200-4.

2. İtil O. Türk toraks derneği temel akciğer sağlığı ve hastalıkları kitabı. 2015;47:359-64.

3. Acıcan T, Ural Ö. Klinik solunum sistemi ve hastalıkları kitabı. 1997;24:468-76.
4. Redline S, Tishler PV. The genetics of sleep apnea. Sleep Med Rev 2000;4:583-602.

5. Mancia G. Autonomic modulation of the cardiovascular system during sleep. N Engl J Med 1993;328:347-9.

6. Guilleminault C, Connolly SJ, Winkle RA. Cardiac arrhythmia and conduction disturbances during sleep in 400 patients with sleep apnea syndrome. Am J Cardiol 1983;52:490-4.

7. Hoffstein V, Mateika S. Cardiac arrhythmias, snoring, and sleep apnea. Chest 1994;106:466-71.

8. Fava C, Montagnana M, Favaloro EJ, Guidi GC, Lippi G. Obstructive sleep apnea syndrome and cardiovascular diseases. Semin Thromb Hemost.2011;37(3):280-96.

9. Grunstein R, Wilcox I, Yang TS, Gould Y, Hedner J. Snoring and sleep apnoea in men: association with central obesity and hypertension. Int J Obes Relat Metab Disord 1993;17:533-40.

10. Wetter DW, Young TB, Bidwell TR, Badr MS, Palta M. Smoking as a risk factor for sleep-disordered breathing. Arch Intern Med 1994;154:2219-24.

11. Mitler MM, Dawson A, Henriksen SI, Sobers M, Bloom FE. Bedtime ethanol increases resistance of upper airways and produces sleep apneas in asymptomatic snorers. Alcohol Clin Exp Res 1988;12:801-5.

12. Partinen M, Telakivi T. Epidemiology of obstructive sleep apnea syndrome. Sleep 1992;15(Suppl 6): S1-S4

13. Winkelman JW, Goldman H, Piscatelli N, Lukas SE, Dorsey CM, Cunningham $\mathrm{S}$. Are thyroid function tests necessary in patients with suspected sleep apnea? Sleep 1996;19:790-3.

14. Grunstein RR, Ho KY, Sullivan CE. Sleep apnea in acromegaly. Ann Intern Med 1991;115:527-32.

15. Leiter JC, Knuth SL, Bartlett DJr. The effect of sleep deprivation on activity of the genioglossus muscle. Am Rev Respir Dis 1985; 132:1242-5.

16. Liu PY, Yee B, Wishart SM, Jimenez M, Jung DG, Grunstein RR, Handelsman DJ. The short-term effects of high-dose testosterone on sleep, breathing, and function in older men. J Clin Endocrinol Metab 2003;88:3605-13. 